\title{
FUKAHÂNIN TEMEL HADİS KAYNAKLARINA REFERANSI VE BU KAYNAKLARIN FUKAHÂ ÜZERİNDEKİ ETKİSI
}

\section{Yusuf EŞİT*}

\section{$\ddot{O} \mathbf{z}$}

Fukahâ ilk dönemden beri hadisle istidlalde bulunmuş; erken dönem hadis kaynaklarından bir kısmı fukahânın ürünü olarak ortaya çıkmıştır. Temel hadis kaynakları tasnif edildikten sonra fukahâ dahil İslami ilimlerle iştigal eden ulemanın tümünün dikkatini celb etmiştir. Bunun sonucunda fikıh eserlerinde hadis kaynaklarına referanslar yapılmıştır. $\mathrm{Bu}$ çalışmamızda, fikıh eserlerinde temel hadis kaynaklarına referansın tarihi seyrini, bu kaynakların mezhep görüşleri üzerindeki etkisini/değişimini tespit edebildiğimiz veriler 1şı̆̆ında ortaya koymaya çalışacağız. Ancak temel hadis kaynaklarının başta fikıh olmak üzere İslamî ilimlerdeki etkisi detaylı araştırmalara ihtiyaç duymaktadır. Bu bağlamda bizim çalışmamız bu ihtiyaca işaret eden bir ön çalışma hüviyeti ile önem arz etmektedir.

Anahtar Kelimeler: fikıh, hadis, tercih, hüküm

\section{RELATION OF FIQH AND MAIN HADITH RESOURCES}

\begin{abstract}
Fukâhâ has been based on hadith since early times and some of the early hadith resources occurred as products of fukâhâ. Main hadith resources attracted the attention of ulama after they were classified. As a result, references were made to hadith sources in fiqh books. In this study, we will try to put forward the histerice processof the references in fiqh sources made to basic sources of hadith and the effects of those on secterian views, in the light of the data available. However, the impact of main hadith resources on islamic sciences especially the fiqh requires detailed resarches. In this context, our study has significant importance as it constitutes a prestudy emphasizingthis need.
\end{abstract}

Keywords: fiqh, hadith, preferenc, judgement

\section{Giriş}

Hadislerin aktarımı Hz. Peygamber döneminden itibaren başlayan bir husustur. Hz. Peygamber'in hadislerinin inananlar açısından bağlayıcı olması hasebiyle sahabe, hadislerin aktarılması ve anlaşılması için ciddi bir çaba içerisine girmiştir. Hz. Peygamber döneminde başlayan hadis rivayeti, tâbiun döneminin sonlarına doğru tedvîn edilmeye başlanmış; hicrî ikinci asırda ise hadisler tasnif edilmiştir. Câmi' türünde hadislerin ilk tasnif edildiği eser olarak Ma'mer'in (ö. 153/770) el-

Makale gönderim tarihi: 24.08.2017, kabul tarihi: 03.11.2017

Doi: 10.26791/sarkiat.336030

*Muş Alparslan Üniversitesi İslami İlimler Fakültesi Temel İslam Bilimleri İslam Hukuku Anabilim Dalı, e-mail: yusufesit11@hotmail.com. 
Câmiu's-Sahîh'i gösterilir. ${ }^{1}$ İlk câmi' türü eserler arasında zikredilen Malik'in (ö. 179/795) el-Muvatta'1 te'lif edildikten sonra genel kabul görmüştür. Öyle ki Şâfîi’nin (ö. 204/820) el-Muvatta'1 Kur'an'dan sonra en sahih eser olarak nitelediği nakledilmektedir. ${ }^{2}$ el-Muvatta'nın h.159'da yazıldığı kabul edildiğinde kendisinden bir asır sonra yazılan Sahîh-i Buhâri'ye kadar geçen sürede sahih hadis kaynağı olarak kabul gördüğü değerlendirilmektedir. ${ }^{3}$ Buhârî'nin elCamiu's-Sahîh'inin ve diğer temel hadis kaynaklarının otoritesinin oluşmasına değin bu kabulün devam ettiğini söylemek mümkündür.

Hicrî III. asır "Kütüb-i Sitte devri” olarak isimlendirilmekte ve hadis tasnîfinin altın çağı olarak nitelendirilmektedir. Bu dönem hadis edebiyatı ana kaynaklarının ortaya çıktığı dönemdir. $\mathrm{Bu}$ devirde yazılan eserlerin temel amacı sahih rivayetlerin bir araya toplanmasıdır. $\mathrm{Bu}$ amaçla yazılan eserler süreç içerisinde Kütüb-i Sitte ${ }^{4}$ olarak isimlendirilmiş ve hadis kaynakları içerisinde en muteberleri olarak kabul görmüştür. ${ }^{5}$

Sünnetin dinin ikinci kaynağı olması hasebiyle erken dönemden itibâren Kur'an'dan sonra güvenilir bir hadis kaynağı arayışı olmuştur. Süreç içerisinde hadis kaynakları da kendi içerisinde sıhhat sıralamasına tâbi' tutulmuştur. Nitekim İbnü's-Salâh (ö. 643/1245) hadis kaynakları içinde Sahîhayn'ın' Allah'ın kitabından (Kur'an) sonra en sahih kitaplar olduğunu ifade etmiştir. Devamında o bu iki sahih eserden Buhârî'nin Sahîhi'nin daha sahih olduğunu ifade etmiştir. Şâfiî̀nin Kur'an'dan sonra en sahih kitabın el-Muvatta' olduğuna yönelik sözünü ise bu iki eserin henüz yazılmamış olmasına hamletmiştir. ${ }^{7}$

Hicrî III. asırdan sonra hadis kaynakları ${ }^{8}$ sadece muhaddisler nezdinde itibar görmemiş aynı zamanda fukahâ nezdinde de kabul görmüştür. Öyleki Sahîhayn'ın ihtiva ettiği hadislerin sıhhati üzerine yemin ve talak meselesi bile ele alınmıştır. Nevevî, İmamü'l-harameyn'in ümmetin bu eserlerin shhhatine yönelik icması

${ }^{1}$ Musa Bağcı, Hadis Tarihi Hicri İlk Üç Asır, Ankara Okulu Yayınları, Ankara, 2009, 202.

2 Bk., Ebû Amr Takıyyüddîn Osmân b. Salâhiddîn Abdirrahmân b. Mûsâ eş-Şehrezûrî, Mukkadimetu İbn Salâh (Ma'rifetu 'Envâ'î 'Ulumi'l-Hadîs), tahk. Nuruddin Itr, Beyrut 1986, 18.

${ }^{3}$ Özet olarak, Bağc1, Hadis Tarihi, 203-205.

${ }^{4}$ Kütüb-i Sitte'nin kavramsallaşma süreci ve hangi hadis eserlerini kapsadığına dair tartışmalar için bk. Bağc1, Hadis Tarihi, 247-258.

${ }^{5}$ Bağc1, Hadis Tarihi, 245.

${ }^{6}$ Buhârî ile Müslim'in Sahih'lerine verilen addır. M.Yaşar Kandemir, "Sahîhayn", DİA, İstanbul 2008, XXXV, s.527.

7 İbn Salâh, Mukkadimetu İbn Salâh, 18. Nevevî de (ö. 676/1277) aynı görüşü benimser ve Sahîhayn'ın Kur'an'dan sonra en sahih eserler olduğu konusunda ulemânın ittifak ettiğini; Sahîhayn'ın ümmet tarafından kabul gördüğünü, Buhârî’nin Sahih'inin ise Müslim'inkinden daha sahih olduğunu belirtir. el-Minhâc Şerhu Sahîhi Müslim, Dâru İhyâi't-Türâsi'l-Arabî, Beyrut, h. 1392, I, 14; et-Takrîb ve't-Teysîr, tahk. Muhammed Osman, Beyrut, 1985, 28.

${ }^{8}$ Bağc1, Kütüb-i hamse'nin (Sahîhayn, Ebû Davud, et-Tirmizî ve en-Nesâî'nin es-Sunen'leri) hicrî beşinci asırda yerleşik ve yaygın kabul gördügünü ifade eder. O, İbn Salâh'ın Ebû Tahir Ahmed b. Muhammed es-Silefî'den yaptığı alıntıyı şu ifadesiyle aktarmaktadır: "Şark ve garb alimleri bu hadis mecmualarının (Sahîhayn, Ebû Davud, et-Tirmizî̀ ve en-Nesâ̂̀'nin es-Sunenleri) sıhhati konusunda ittifak etmiştir" (Hadis Tarihi, 251). Bağcı'nın belirttiğine göre İbn Mâce'nin esSunen'inin bu eserlere dahil olup Kütüb-i Sitte kavramının oluşması daha sonraki bir süreçte hicrî yedinci asırdan itibarendir (Hadis Tarihi, 258). 
sebebiyle böylesi bir talakın vaki olmadığı ve yeminin bozulmadığı görüşünde olduğunu aktarır. ${ }^{9}$

Fukahâ gerek kendi mezheb görüşlerinin temellendirilmesinde, gerek karşıt görüşlerin çürütülmesinde, gerekse ulaşılmış hükümden farklı bir hükme varmada ölçüt olarak bu kaynaklarda geçen hadisleri kullanmışlardır. Örneğin; Hanefî Fakih Kudûrî (ö. 428/1037), Şâfî̂’lerin veli ve iki adil şahid olmaksızın nikâhın olmayacağına dair delil olarak kullandıkları hadisin Sahîhayn'da zikredilmemiş olmasının hadisin tenkidi için yeterli bir sebep olduğunu ve Ebû Davud'un da Şâfîiler'in dayandığı hadisi kitabında yer vermediğini belirtir. ${ }^{10}$ Şâfîi fakih Mâverdî (ö. 450/1058), nebizin hükmünü tartışırken muarızının ileri sürdüğü

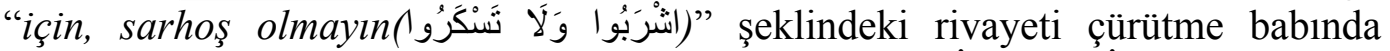

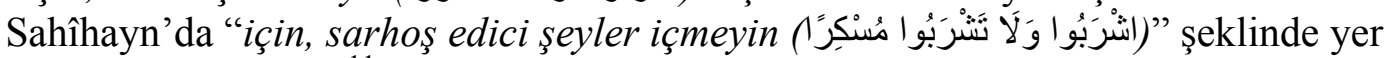
aldığını belirtmiştir. ${ }^{11}$ Görüldügüü üzere Mâverdî Sahîhayn'da yer alan rivâyeti muârızının görüşünün çürütülmesinde referans kaynağı olarak kullanmıştır. Aynı asırda yaşamış olan Şâfiî usûlcü Sem ‘ânî (ö. 489/1096) de Kavâtiü’l-Edille adlı usul eserinde aktardığı bir hadisin sıhhatine işaret etmek adına Sahîhayn'1 referans göstermiştir. ${ }^{12}$ Hanbelî fakih İbn Kudâme (ö. 620/1223) de, kasâme konusunda önce yemin etmesi gereken taraf hakkındaki tartışmaları ele alırken kendilerinin görüşüne dayanak olarak zikrettiği hadis hakkında değerlendirmelerde bulunduktan sonra "Bizim hadisimiz, Sahîhayn'ın (Buhârî ve Müslîm) tahriç edip ittifak ettikleri bir hadistir. Onların dayandığl hadis ise bu hadise muhaliftir." 13 şeklinde ifadede bulunmuştur. $\mathrm{Bu}$ değerlendirmelerde Sahîhayn olarak Buhârî ve Müslim'in rivayetlerinin kendi görüşlerinin doğruluğuna; muârızların görüşlerinin yanlışlığına hadis kaynağı olarak başvurulduğu görülmektedir.

Mezkûr hadis kaynaklarının gördüğü itibar aynı zamanda hadis ilminin ve muhaddislerin de itibar sahibi oldukları anlamına gelmektedir. Nitekim Şâfiî usûlcü Sem'ânî sahih hadisi şöyle tanımlamaktadır: "Bize göre sahih hadis, ehli hadisin sahih gördüğ̈̈dür" "14. Sem‘ânî, haberin sahih, meşhur, münker veya garip olduğunu bilmenin ancak râvîlere dâir bilgiye dayandığını söyler. Ona göre evlâ olan bu konulardaki hükmü ehline (muhaddislere) bırakmak ve onlara sormaktır. ${ }^{15}$ Sem‘ânî sahih hadis tanımına yönelik soruya Hâkim en-Nisâburî’nin (ö. 405/1014) Ulûmü'l-Hadîs'inde verdiği tanımı zikreder. ${ }^{16}$ Hicrî V. asrın sonlarında

\footnotetext{
${ }^{9}$ Nevevî, Minhâcu Sahîhi Müslim, I, 19.

${ }^{10}$ Ebü'l-Hüseyn Ahmed b. Ebî Bekr Muhammed b. Ahmed el-Kudûrî, et-Tecrîd li'l-Kudûrî, tahk. Muhammed Ahmed Sirâc-Ali Cuma Muhammed, Dârü's-Selâm, Kâhire 2006, IX, s.4359.

11 Ebü'l-Hasen Alî b. Muhammed b. Habîb el-Basrî el-Mâverdî, el-Hâvi'l-Kebîr fi Flkhi Mezhebi'l-Imâmi'ş-Şâfî̀, tahk. Ali Muhammed Maavvad-Adil Ahmed Abdü'l-Mevcud, Dârü'lKütübi'l-İlmiyye, Beyrut 1999, XIII, 403.

12 Ebü'l-Muzaffer Mansûr b. Muhammed b. Abdilcebbâr et-Temîmî el-Mervezî es-Sem‘ânî, Kavâti 'u'l-Edille fi'l-Usûl, tahk. Muhammed Hasan Muhammed Hasan İsmail, Beyrut, 1999, I, 147.

${ }^{13}$ Ebû Muhammed Muvaffakuddîn Abdullāh b. Ahmed b. Muhammed b. Kudâme el-Cemmâîlî elMakdisî, el-Mŭgnî, Mektebetü'l-Kahire, y.y 1968, VIII, 499.

${ }^{14}$ Sem'ânî, Kavâti 'u'l-Edille, I, 397.

${ }^{15}$ Sem 'ânî, Kavâti 'u'l-Edille, I, 399.

${ }^{16}$ Sem 'ânî, Kavâti ‘u’l-Edille, I, 399.
} 
bir usulcünün muhaddislerin tanımlarını esas alıp hadis usulü eserine referansta bulunması fikıh-hadis ilimleri ilişkisi açısından önem arz etmektedir.

Temel hadis kaynakları dediğimiz Kütüb-i Sitte, özellikle de Sahîhayn genel kabule mazhar olunca Sahîhayn'daki rivayetlerin bilgi değeri problemi ortaya çıkmış, söz konusu eserlerde geçen bilginin kat'î mi; yoksa zannî bilgi mi ifade ettiği tartışılmıştır. Nevevî, İbnü's-Salâh'ın Sahîhayn'da bulunan rivayetler ile her birinde bulunup diğerinde bulunmayan rivayetlerin sihhatinin kesin olup, kat ${ }^{6} \hat{i}$ bilgi ifade ettiği şeklindeki görüşünü aktarır. Ancak kendisi, muhakkik ve cumhur-u ulemânın bu rivayetlerin zann ifade ettiği; kat'î bilginin ancak tevâtürle sağlandığı görüşünde olduklarını belirtir. ${ }^{17}$ Aynı şekilde Hanefî fakih İbn Emîri'lHâc el-Halebî (ö. 879/1474) de et-Takrîr ve't-Tahbîr adlı usul eserinde İbnü'sSalâh'ın Sahîhayn rivayetlerinin kat'î bilgi ifade ettiğine yönelik görüşüne yer verdikten sonra fukahâ ve muhaddislerin çoğunluğunun bu rivayetlerin mutlak olarak (karineli veya karinesiz) kat'î bilgi ifade etmediği görüşünde olduklarını ifade eder. ${ }^{18}$

Nevevî, Sahîhayn'daki mütevatir olmayan rivayetlerin ahad haber olmalarından ötürü zann ifade ettiklerini belirtir. O, Buhârî ve Müslim'in hadisleri ile diğer hadisler arasında bu anlamda bir fark görmez. Nevevî'ye göre ümmetin onları kabulle karşılaması, onlardaki rivayetleri ayrıca araştırmaya gerek olmadan amel etme açısından bir kolaylık sağlamaktadır. ${ }^{19}$ Ona göre diğer kaynaklardaki rivayetlerle ise ancak araştırıp sıhhat şartları belirlendikten sonra amel edilebilir. Bunların da sihhati belirdiğinde onlarla amel etmek vacip olur. Dolayısıyla ümmetin kabulüne mazhar olma, amel etmenin vucubiyetine dâir olup kesin bilgi ifade etmesine yönelik değildir. Ümmetin, Buhârî ve Müslim'in rivayetleriyle amel etmenin gereği üzerinde icmâ etmiş olmaları, bu rivayetlerin kesin olarak Hz. Peygamber'in sözü olduğu üzerinde ittifak ettikleri anlamına gelmez. ${ }^{20}$

Gazzâlî (ö.505/1111), bir kimsenin müctehid olması için gereken şartları sayarken rivayetlerin sahihini ve sakimini birbirinden ayırt edebilmeyi şart koşar. O, rivayetin kabulü için âdilin âdil olmayandan yaptığı rivayetlerin geçerli olmadığını; bir ravinin adâletinin ise ya deneyim ya mütevâtir haber ya da müşâhede ile bilinebileceğini; bunun dişındakinin taklit olduğunu belirtir. Gazzâlî; râvinin ta'dîli işinin uzun bir uğraş gerektirdiğini, râvi ile aralarında geçen zaman diliminin de ta'dîl işini zorlaştırdığını ifade eder. O, ümmetin kabulüne mazhar olan hadislerin isnâdının araştırılmasına gerek olmadığına yönelik görüşü, işin kolaylığına bağlar. Gazzâlî, Buhârî ve Müslim'deki rivayetlerin de bu kapsamda olduğunu; onların, adâletine inandıkları râvilerin rivâyetini eserlerine aldıklarını söyler. Dolayısıyla fetva verecek kimsenin, imamların râvilerinden razı oldukları (âdil olarak kabul ettikleri) sahih kitapları

\footnotetext{
${ }^{17}$ Nevevî, et-Takrîb, 28.

${ }^{18}$ Ebû Abdillâh Şemsüddîn Muhammed b. Muhammed b. Muhammed el-Halebî, et-Taķrîr ve'tTahbîr, Dârü'l-Kütübi'l-İlmiyye, 1983, II, 268.

19 Gazzâlî, kıyasa dair sünnetten dayanak olarak gösterilen Hz. Peygamber'in Muâz ile olan diyaloga dair rivayetin ümmetin genel kabulüne mazhar olduğunu; dolayısıyla ayrıca isnadını araştırmaya gerek olmadığını belirtir. (Ebû Hâmid el-Gazzâlî, el-Mustasfâ, tahk. Muhammed Abdüsselam Abdü'ş-Şâfîi, Dârü'l-Kütübi'l-İlmiyye, 1993, 293).

${ }^{20}$ Nevevî, Minhâcu Sahîhi Müslim, I, 19-20.
} 
taklit etmesinin, yolunu kısaltacağını; kendisini külfetli ve zahmetli bir uğraştan da kurtaracağını ifade eder. ${ }^{21}$ Gazzâlî kısaca isnat araştırmasının yapıldığını tekrar yapmaya çalışmanın hem güç hem de zaman kaybı olduğunu; bu hususta imamların kabul ettiği sahihlerin fetva vermek için başvurulabilecek kaynak olmasının caiz olduğunu anlatır. $\mathrm{Bu}$ yaklaşım aynı zamanda temel hadis kaynaklarının fakihler nezdinde kabul görme gerekçesini de ifade etmektedir.

Sonuç olarak fakihlerin Sahîhayn'da geçen rivayetlerin sırf bu kaynaklarda geçmeleri sebebiyle amele kâbil olmadıkları; bunun ötesinde ümmetin mazharına nâil olmalarının ihtiva ettikleri ahad haberi kat'î bilgi derecesine çıkartmadığ1; ancak bu durumun senedi inceleme ihtiyacı hissetmeden amel etme açısından kolaylık sağladığı görüşünde olduklarını söyleyebiliriz. Bununla beraber fukahâ nezdinde sahih hadis kaynaklarındaki bazı hadislerin sıhhatı ile ilgili tartışmalar da yaşanmıştır.

Hanefî fakih Kudûrî, sahih eserlerden sayılmasa da kendisi dahil her mezhepten fakihin referansta bulunduğu Dârekutnî'nin nikahta veli izni meselesine dair sahih olmayan haberleri eserine alıp bu raviler hakkında değerlendirme yapmayıp sessiz kalmasına yönelik şaşkınlığını dile getirir. ${ }^{22}$ Mâlikî fakih İbn Rüşd (ö. 595/1198), sarık üstüne meshi caiz görmeyenlerin (Malik, Ebû Hanife ve Şâfîi) Müslim'de geçen "alnını, sarığını ve mestini meshetti" şeklinde Muğîre b. Şube rivayeti ile amel etmemelerinin bu rivayetin ya Kur'an'ın açık ayetine (başın meshedilmesini isteyen Maide suresinin altıncı ayeti) aykırı olduğu ya da ahad haberin kabulü için şöhreti -özellikle Medine ehlince- şart kabul edenlerce meşhur olmaması gibi gerekçeleri olduğunu belirtikten sonra Ebû Ömer İbn Abdilberr'in (ö. 463/ 1071) hadis hakkında illetli olduğuna dair değerlendirmesini aktarır. ${ }^{23}$ İbn Rüşd, Müslim'de geçen bir rivayeti hem ayetle birlikte değerlendirmekte hem de Malikî usûlünün süzgecinden geçirmektedir. Bu konuyla alakalı olarak Şâfîi fakihi Nevevî de ilgili rivayetleri zikrettikten sonra Hz. Peygamber'in sadece sarı̆̆ meshettiğine dair rivayeti ya hem sarı̆̆ meshettiğine dair rivayetler ile açık Kur'an ayetine uygun olarak yorumlanacağını, ya da onlara aykırı olduğu şeklinde değerlendirilebileceğini ifade eder. O, konuyla alakalı diğer hadis ve açı Kur'an ayetiyle uyumlu olarak yorumlamanın daha uygun olduğunu belirttikten sonra sarık üzerine meshi rivayet edenlerin başı zikretmemelerinin, başı meshetmenin bilinen bir husus olmasından kaynaklandığ 1 yönünde mezhep içinde kimi fukahânın değerlendirmesini aktarır. ${ }^{24}$

21 Gazzâlî, el-Mustasfâ, 344. Sübkî’nin aktarımına göre Ebû Şâme hadis kaynaklarının kolaylaştırıcı işlevine vurgu yaptıktan sonra bunlarla meşgul olmamanın hiçbir mazereti olamadığını belirtir (Ebü'l-Hasen Takıyyüddîn Alî b. Abdilkâfî b. Alî b. Temmâm es-Sübkî, Ma'nâ Kavli'l-İmâm el-Muttalibî İzâ Sahha'l-Hadîs Fehüve Mezhebi, Dârü'l-Beşâiri'l-İslâmiyye, Lübnan 1994, 140).

${ }^{22}$ Kudûrî, et-Tecrîd li'l-Kudûrî, II, 501. Kudûrî'nin Dârekutnî'yi sahih olmayan haberleri eserine almasını eleştirmesi yanında kimi hadislerin sıhhati için onu referans göstermesinden mezhebin görüşünün hadis kaynaklarından temellendirilmesi amacının olduğu söylenebilir. Ehli hadisin sosyo-politik açıdan güçlü olduğu bir dönemde diğer mezheplerin referansta bulunduğu hadis kaynaklarının kullanılması reel duruma uyumlulukla izah edilebilir.

${ }^{23}$ Ebü'l-Velîd Muhammed b. Ahmed b. Ahmed el-Kurtubî el-Endelüsî, Bidâyetü'l-Müctehid ve Nihâyetü'l-Müktesid, Dârü'l-Hadis, Kahire, 2004, I, 21.

${ }^{24}$ Nevevî, el-Mecmû' Şerhu'l-Mühezzeb, Dârü'l-Fikr, y.y. t.y., I, 408-409. 
Nevevî de konuyla alakalı Ebû Dâvûd ve diğer sahih hadis kaynaklarında geçen rivayetleri bütüncül bir şekilde ele almakta sadece sarığa meshi aktaran ravileri mazurlu gösterme yaklaşımı benimsemektedir.

Hanbelî fakih İbn Müflih (ö. 763/1362) cünüpken sabahlayıp yıkanan kimsenin orucunun sahih olduğunu belirttikten sonra Sahîhayn'da geçen "Kim cünüplü olarak fecre ulaşırsa oruç tutmasın..." şeklindeki hadisin ya fecr olmadan yıkanmanın sünnet olduğunu ifade ettiğini, ya da nesh olduğunu belirtmektedir. Delil olarak da Allah'ın fecre kadar cimâyı helal kılmasını ve Peygamber'in yine Sahîhayn'da geçen cünüp iken sabahladığına dair rivayeti aktarır. ${ }^{25}$ İbn Müflih'in, aktarılan rivayeti ayet ve hadisle birlikte ele alması bu kaynaklardaki hadislere yönelik fukahânın tavrına bir örneklik teşkil etmektedir. Nitekim hemen bu rivayetten yola çıkarak rivayetin geçtiği hadis kaynağını ve müellifini eleştirmemiş hadisin sıhhatini de tartışmaya açmamıştır. Bu tutum İbn Müflih'in yaşadığı asırda Kütüb-i Sitte'ye yönelik genel kabulün olduğunun bir göstergesidir.

\section{Fukahânın Temel Hadis Kaynaklarına Referansının Tarihî Seyri (Hicrî VIII. Asra Kadar)}

Fukahâ Kur'an'dan sonra ikinci bilgi kaynağı olması hasebiyle hadislere ilk dönemden itibâren eserlerinde yer vermişlerdir. Fıkıh alanında elimize ulaşmış ilk kaynaklara baktığımızda bu hususu açık bir şekilde görmekteyiz. Örneğin; Şâfîi’nin el-Ümm adlı eserinin ilk satırlarına baktığımızda taharet bahsine ayet (Maide/6) ile başlamaktadır. Âyeti îzah ettikten sonra âyetin zahirine mutabık ama isnâdında tanımadığını söylediği birinin yer aldığı bir rivayetin aktarıldığını belirtmektedir. Daha sonra ise Ebu Hüreyre- el-Muğîre b. Ebî Bürde- Said b. Seleme- Süleym- Safvan- Malik isnadıyla konuya dair başka bir hadisi zikretmektedir. ${ }^{26}$ Yine Şâfîi kendisinden önce yaşamış olan ve câmi türünün ilk örneğini el-Câmiu's-Sahih'in müellifi Ma'mer b. Raşid'in rivayetlerine yer vermektedir. Ancak bu, kitap ismi olmaksızın isnâd zinciri ile olmaktadır. ${ }^{27}$ Diğer fukahânın eserlerinde de durum bundan farklı değildir. Malik'in el-Muvata'ı ilk câmî türü eserler arasında zikredilirken, eş-Şeybânî'nin (ö. 189/805) el-Âsâr'1 günümüze ulaşmış en eski hadis kaynaklarından biri olarak sayılmaktadır. ${ }^{28}$

İlk dönemden beri fakihler hadisle iştigâl etmiş; hadise dair müstakil eserler telif etmekle beraber kendi eserlerinde de hadislerle istidlâlde bulunmuşlardır. Süreç içerisinde ilimler ayrışmış ve her ilimde uzmanlaşma kendini göstermiştir. Bununla beraber bir bütünün parçaları olması hasebiyle İslâmî ilimlerin birbirileriyle olan ilişkileri devam etmiştir. Özellikle hicrî III. asırda muhaddislerce tasnif edilen temel hadis kaynakları diyebileceğimiz Kütüb-i Sitte sonraki asırlarda ümmet tarafindan genel kabul görmüş ve ulemânın müstağni kalamayacağı eserler haline gelmiştir. $\mathrm{Bu}$ noktada mezheplerin temel hadis kaynaklarına müracaatlarına hangi asırda ve hangilerine başvurduklarını tespit etmek fıkıh hadis ilimleri arasındaki ilişki açısından önem arz etmektedir. Biz de

\footnotetext{
${ }^{25}$ Ebû Abdillâh Şemsüddîn Muhammed b. Müflih b. Muhammed el-Makdisî er-Râmînî, Kitâbü’lFurû', tahk. Abdullah b. Abdullah el-Muhsin et-Türkî, Müessesetü'r-Risâle, 2003, V, 17.

${ }^{26}$ Ebû Abdillâh Muhammed b. İdrîs b. Abbâs eş-Şâfî̂, el-Ümm, Dârü’l-Marife, Beyrut 1990, I, 16.

${ }^{27}$ Bk. Şâfiî, el-Ümm, IV, 227; VI, 38; VII, 140; VII, 339.

${ }^{28}$ Bk. Mehmet Özşenel, Şeybânî, DİA, İstanbul 2010, XXXIX, 42.
} 
matbû eserler çerçevesinde başta Kütüb-i Sitte olmak üzere meşhur olan temel hadis kaynaklarına referansların tarihi seyrini inceleyeceğiz. Biz bu incelememizi el-Mektebetü'ş-şâmile programını kullanarak yaptık.

Hicrî IV. asır fikıh kaynaklarında Kütüb-i Sitte kaynaklarına referanslar yapılmaya başlandığını görmekteyiz. Hanbelî fakih Hallâl (ö. 311/923) el-Vukûf ve't-Tereccül adlı eserinde Ebû Davud'a referanslarda bulunmaktadır. ${ }^{29}$ Hanefî fakih Cessâs (ö. 370/981) da Şerhu Muhtasari’t-Tahâvî adlı eserinde Ebû Dâvûd'a referanslarda bulunmaktadır. ${ }^{30}$

Hicrî V. asırda Mâlikî, Hanefî, Şâfîi ve Hanbelî kaynaklarında Kütüb-i Sitte kaynaklarına referansların yapıldığını görüyoruz. Bu asırda Mâlikî fakih İbn Abdülber en-Nemerî (ö. 463/1071), el-Kâfî adlı eserinde Ebû Dâvûd'un Sünen'ine referansta bulunmaktadır. Hanefi fakihi Kudûrî, et-Tecrîd adlı eserinde Sahîhayn'a ${ }^{31}$, Buhârî'ye, ${ }^{32}$ Müslim'e ${ }^{33}$, Ebû Davud'a ve Dârekutnî'ye ${ }^{34}$ referanslar yapmaktadır. Yine bu asır Hanefi fakihlerinden Serahsî (ö. 483/1090 ) Ebû Davud ${ }^{35}$ ve Dârekutnî’ye ${ }^{36}$ referansta bulunmaktadır. Bu asrın Şâfiî fakihlerinden Mâverdî de Sahîhayn'a ${ }^{37}$, Buhârî'nin Sahih'ii ${ }^{38}$ ile Müslim'in Sahîhi'ne $^{39}$, Ebû Davud ${ }^{40}$, Tirmizîn ${ }^{41}$ ve Dârekutnî'nin ${ }^{42}$ Sünen'lerine atıfta bulunmaktadır. Mâverdî'nin Sahîhayn'a atıf sebebi muârızının hadisini bu iki sahihe arz etmektir. Bu husus hicrî V. asırda muhaddislerce kullanılan ve muteber görülen Sahîhayn'ın hadis kaynağı olarak fakihlerce benimsendiğini göstermektedir. Yine bu dönem Şâfiî fakihlerinden Sem'ânî'nin eserinde Buhârî ve Müslim'in sahihlerine, Ebû Dâvûd ile Dârekutnî'nin sünenlerine atıf yaptığını

\footnotetext{
${ }^{29}$ Ebû Bekir Ahmed b. Muhammed b. Hârûn el-Hallâl el-Bağdâdî, el-Vukûf ve 't-Tereccül min 'e'lCâmi 'i li Mesâili'l-İmam Ahmed b. Hanbel, Tahk. Seyid Kesrevi Hasan, Dârü'l-Kütübi'l-İlmiyye, Birinci Bask1, 1994, 22, 72, 111, 122, 123, 124, 126, 130, 136, 145.

${ }^{30}$ Ebû Bekr Ahmed b. Alî er-Râzî, Şerhu Muhtasari't-Tahâvî, Dârü'l-Beşâirü'l-İ̀slâmiyye/Dârü'sSirâc, Birinci Bask1, 2010, I, 362. Kimi yerlerde, Ebû Davud es-Sicistânî (I, 204, 244, 375, 443; VIII, 541), kimi yerlerde sadece Ebû Davud şeklinde referanslar yapmaktadır. Bu şekilde ki referanslar zikredilmeyecek kadar çoktur (yaklaşık doksan defa). Ebû Davud'tan ya Sünen'inden veya (ekserisi) Muhammed $b$. Bekr aracılığıla rivayet etmektedir.

${ }^{31}$ Kudûrî, et-Tecrîd, II, 50; IX, 4353, 4359; XI, 6017.

${ }^{32}$ Buhârî Sahih'inde şeklinde ifade için bk. Kudûrî, et-Tecrîd, I, 489; IV, 1705; X, 5400.

${ }^{33}$ Müslim Sahih'inde şeklindeki ifade için bk. Kudûrî, et-Tecrîd, I, 71.

${ }^{34}$ Eserde doksan civarında Ebû Davud'a yüz otuza yakında Dârekutnî’ye referans yapılmaktadır. Referanslar çok olduğundan zikretmeyeceğiz.

${ }^{35}$ Ebû Bekr Şemsü'l-eimme Muhammed b. Ebî Sehl Ahmed es-Serahsî, el-Mebsût, Dârü'l-Marife, Beyrut 1993, I, 5, 56; II, 152; III, 73.

${ }^{36}$ Serahsî, el-Mebsût, XIII, 139.

37 Mâverdî Sahîhayn kavramını Buhârî ve Müslim'in ittifak ettiği rivayetler anlamında kullanmaktadır. (el-Hâvi'l-Kebîr, XIII, 403)

${ }^{38}$ Mâverdî, el-Hâvi'l-Kebîr, XII, 7.

${ }^{39}$ Mâverdî, el-Hâvi'l-Kebîr, XVII, 71.

${ }^{40}$ Mâverdî, el-Hâvi'l-Kebîr, I, 180, 186, 209, 213, 215, 331, 351, 373, 442; II, 92, 106, 117, 156, 249, 380, 406, 458; III, 34, 236, 384; IV, 342; V, 100, 132, 237, 342, 388; VII, 229; VIII, 417, IX; 122, 316; XI, 171; XII, 309, XIII, 5, 354, 394; XVII, 161; XVIII, 7.

${ }^{41}$ Mâverdî, el-Hâvi'l-Kebîr, V, 132; XV, 74.

${ }^{42}$ Bk. Mâverdî, el-Hâvi'l-Kebîr, I, 328; II, 38; IX, 41; X, 27, 121, 185, 260, 517; XI, 317,330; XII, 168, 215; XIII, 157,365, 471; XVI, 78, 142; XVII, 73; XVIII, 248.
} 
görüyoruz. ${ }^{43}$ Bu asır Hanbelî fakihlerinden Ebû Ali el-Hâşimî (ö. 428/) el-İ̇şâd ilâ Sebîli'r-Reşâd adlı eserinde Buhârî’ye iki defa ${ }^{44}$ Ebû Dâvûd'a bir defa ${ }^{45}$ referansta bulunmaktadır. Yine bu asır Hanbelî fakihi Ebû Ya'la el-Ferrâ (ö. 458/1066) da el-Mesâilü'l-Fikhiyye adlı eserinde Ebû Dâvûd ${ }^{46}$ ve Buhârî'ye ${ }^{47}$; et-Ta'lîkatü'lKebîr fi'l-Mesâili'l-Hilâf alâ Mezhebi Ahmed adlı eserinde ise Ebû Davud ${ }^{48}$ ve Dârekutnî'ye ${ }^{49}$ çokça referansta bulunmaktadır.

Hicrî VI. asır Hanefî̀ fakihlerinden Semerkandî (ö. 539/1144) eserinin bir yerinde Şâfiî'nin görüşüne karşı kendi görüşünün sahihliğini ispat sadedinde Dârekutnî'nin Sünen'ine referansta bulunmaktadır. ${ }^{50}$ Yine hicrî VI. asır fakihlerinden Kâsânî (ö. 587/1191) de kendi eserinde Sahîhayn'a ${ }^{51}$, Müslim'in Sahih'ine ${ }^{52}$, Ebû Davud ${ }^{53}$ ve Dârekutnî'nin ${ }^{54}$ Sünen'lerine atıfta bulunmaktadır. $\mathrm{Bu}$ asırda Malikî kaynaklarında referanslar bir önceki asra göre daha fazlalaşmıştır. Sahîhayn ${ }^{55}$ başta olmak üzere Ebû Dâvûd, Nesâî, Tirmizî'ye referanslar artmıştır. Öyle ki İbn Rüşd (ö. 595/1198) Bidâyetü'l-Müctehid adlı eserinde neredeyse zikrettiği tüm hadislerin sıhhat durumunu tartışırken İbn Mâce hariç diğer Kütüb-i Sitte eserlerine sürekli -dipnotta zikredemeyeceğimiz kadar çok- referansta bulunmaktadır. Bu husus hicrî VI. asrın son çeyreğinde Mâlikî fakihlerin nezdinde kütüb-i hamsenin güvenilir hadis kaynakları olarak kabul edildiğini göstermektedir. Bu asır Şâfiî fakihlerinden olan Gazzâlî, el-Vasît adlı eserinde Buhârî ${ }^{56}$ ve Dârekutnî'ye ${ }^{57}$ birer kez referansta bulunmaktadır. VI. asrın ortalarında yaşamış olan İmrânî (ö. 558/1163) el-Beyân adlı eserinde, Gazzâlî’ye

\footnotetext{
${ }^{43}$ Sem ‘ânî, el-İstilâm fi'l-Hilâf Beyne 'l-İmâmeyni eş-Şâfî̀ ve Ebî Hanife, tahk. Nayif b. Nafi' elUmrî, Dârü'l-Menâr, Birinci Bask1, 1992, Sahîhayn için bk. I, 81, 171, 296; II, 220; Buhârî için bk. I, 98, 217; Müslim için bk. I, 217, 243, 246; II, 297; Ebû Davud için bk. I, 59, 96, 106; II, 102, 104, 127, 178, 200, 352; Dârekutnî için bk. I, 62,103, 172, 191, 216, 222, 301; II, 104, 106, 108 , 200, 201, 202, 251, 284, 314.

${ }^{44}$ Muhammed b. Ahmed b. Ebî Musa el-Hâşimî, el-İrşâd ilâ Sebîli'r-Reşâd, tahk. Abdullah b. Abdullah el-Muhsin et-Türkî, Müessesetü'r-Risâle, y.y. t.y., 9,150.

${ }^{45}$ Ebû Ali el-Hâşimî, el-İrşâd ilâ Sebîli'r-Reşâd, 139.

${ }^{46}$ Ebû Ya'lâ Muhammed b. el-Hüseyn b. Muhammed b. Halef el-Ferrâ', el-Mesâilü'l-Fikhiyye mik kitâbi'r-Rivâyeteyni ve'l-Vecheyni, tahk. Abdülkerim b. Muhammed, Mektebetü'l-Me'arif, Riyâd 1985, II, 272, 280; III, 126.

${ }^{47}$ Ebû Ya'lâ el-Ferrâ, el-Mesâilü'l-Fikhiyye, I, 424; II, 248, 249.

48 Ebû Ya'lâ el-Ferrâ, et-Ta'lîkatü'l-Kebîr fi'l-Mesâili'l-Hilâf alâ Mezhebi Ahmed, Dârü'nNevâdir, 1. Bask1, y.y. 2010, I,39, 59, 60, 218, 221, 248, 350, 384, 476; II, 105, 144, 147, 322, $535,375,433,436,439$.

${ }^{49}$ Ebû Ya'lâ el-Ferrâ, et-Ta 'lîkatü'l-Kebîr, I, 5, 6, 16, 54, 55, 139, 470; II, 65, 70, 74; III, 14, 161, $166,171,175,196,209,218,255,259,386$.

${ }^{50}$ Semerkandî, Tuhfetü'l-Fukahâ, Dârü'l-Kütübi'l-İlmiyye, Beyrut 1994, II, 115.

${ }^{51}$ Alâüddîn Ebû Bekr b. Mes'ûd b. Ahmed el-Kâsânî, Bedâ 'i' ï's-Sanâ 'i fi Tertîbi'ş-Şerâi ‘,Dârü'lKütübi'l-İlmiyye, 2. Bask1, y.y 1986, II, 249.

${ }^{52}$ Kâsânî, Bedâ 'i' ü's-Sanâ 'i, I, 16.

${ }^{53}$ Kâsânî, Bedâ 'i'ü's-Sanâ 'i, I, 23, 72; III, 142; IV, 47; V, 100; VII, 16.

${ }^{54}$ Kâsânî, Bedâ 'i' '̈'s-Sanâ 'i, II, 220.

${ }^{55}$ Bk. Ebü'l-Velîd Muhammed b. Ahmed b. Ahmed el-Kurtubî el-Endelüsî, el-Beyân ve't-Tahsîl, tahk. Muhammed Hacî, Dârü'l-Ğarbi'l-İslâmî, Beyrut, 1988, XI, 355; III, 474; XVII, 31; İbn Rüşd el-Hafîd, Bidâyetü'l-Müctehid, I, 20, 21, 131; II, 93; III, 84, 145.

${ }^{56}$ Gazzâlî, el-Vasît fi'l-Mezheb, Dârü's-Selâm, Birinci Baskı, Kahire, h.1417, II, 110.

${ }^{57}$ Gazzâlî, el-Vasît, IV, 40.
} 
nispeten hadis kaynaklarına daha fazla referansta bulunmaktadır. ${ }^{58}$ İmrânî'nin başvurduğu kaynaklar içerisinde Ebû Davud'a yapılan referansın diğerlerine nazaran daha fazla olması dikkat çekmektedir. Hicrî VI. asra dâir Hanbelilerin elimizde matbû yeterli derecede kaynakları bulunmamaktadır. Dolayısıyla bu asırlarda hadis kaynaklarına yönelik tutumları hakkında isabetli bir karar vermek güçtür. Bu dönemlere ait iki eserden biri olan el-Mesâilü'l-letî Hâlefe aleyhâ Ahmed detaylı ve tüm konulara şamil bir fikıh eseri değildir. Diğer eser el-Hidâye ala Mezhebi Ahmed eserinde hadisle istidlâle çok az yer vermiştir. Eseri tahkik eden Abdüllatif el-Hümeym ve Mâhir Yasin Fahl, müellifin bazı yerlerde hadise yer verdiği tespitinde bulunmaktadır. ${ }^{59}$

Hicrî VII. asır fikıh eserlerinde Kütüb-i Sitte eserlerinin tümüne referanslar yapılmış olup; fıkıh kaynaklarında daha önceki asırlarda kendisine referans yapılmayan İ̉n Mâce'ye referans yapıldığını görmekteyiz. ${ }^{60}$

Hicrî yedinci asır Şâfiî fakihi er-Râfîînin (ö. 623/1226) Fethü'l-‘Azîz adlı eserinde Kütüb-i Sitte kaynaklarının tümüne referansta bulunduğunu; ancak bunun düşük yoğunlukta olduğunu söyleyebiliriz. Aynı asırda yaşamış olan ve aynı zamanda muhaddis kimliğiyle ön plana çıkan İbnü's-Salâh $(643 / 1245)$ bir rivayeti aktarırken şu cümleyi sarf etmektedir: "Ebû Dâvûd es-Sicistânî'nin, Eb̂̂u

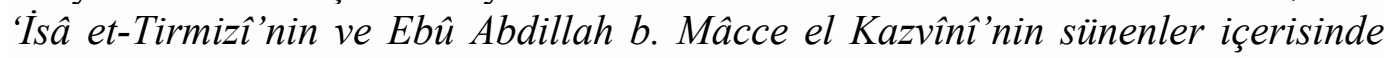
mûtemed olan kitablarında rivâyet ettiklerini...". Muhaddis kimliğinin yanında iyi bir fakih olan İbnü's-Salâh'ın bu sözleri Edebü'l-Müftî ve'l-Müsteftî'nin hemen girişinde bir hadisi naklederken zikretmesi önemlidir. ${ }^{61}$ Aynı müellifin Şerhu Müşkili'l-Vasît adlı eserinde her hadisin hadis kaynaklarından tahrîcini yapmakta ve onların yorumlarını aktarmaktadır. ${ }^{62}$ Yedinci asrın ikinci yarısı fukahâsından Nevevî'nin el-Mecmû' adlı eserine baktığımızda ise her hadisin geçtiği hadis kaynağının verildiği, hadisler hakkında muhaddislerin yorumlarının zikredildiği

58 Ebü'l-Hüseyn Yahyâ b. Ebi'l-Hayr b. Sâlim b. Es'ad el-İmrânî el-Yemânî, el-Beyân $f i$ Mezhebi'l-İmam eş-Şâfî̀, Dârü'l-Minhâc, Birinci Bask1, Cidde 2000, Tirmizî için bk. II, 412; III, 41,60; VII, 508. Müslim için bk. VII, 98. Buhârî için bk. II, 29, 33, 67; VII, 97. Ebû Davud için bk. II, 63, 158, 201, 233, 241, 253, 302, 312, 319, 412, 517; III, 547; IV, 198, 464; V, 126; IX, 244,; X, 587, XI, 288, XII, 385, XIII, 279.

59 Bk. Ebü'l-Hattâb Mahfûz b. Ahmed b. el-Hasen el-Kalvazânî el-Bağdâdî, el-Hidâye alâ Mezhebi Ahmed, Gürâs li’n-Neşri ve’t-Tevzi‘̂̂, Birinci Baskı, Kuveyt 2004, 20.

${ }^{60}$ Hanefilerde İbn Macce'ye yapılan referans için bk. Cemâlüdîn Ebû Muhammed Ali b. Ebî Yahya Zekeriya b. Mes ‘ud el-Hazrecî el-Ensârî, el-Lübâb fî̀l-Cem 'i Beyne's-Sünneti ve'l-Kitâb, tahk. Muhammed Fadl Abdülaziz el-Murâd, Dârü'l-Kâlem, Sûriye 1994, I, 132. Malikî kaynağ1 için bk. Ebü'l-Abbâs Şihâbüddîn Ahmed b. İdrîs b. Abdirrahmân el-Misrî el-Karâfî, ez-Zahîre, tahk. Muhammed Hacî ve diğerleri, Dârü'l-Ğarbi'l-İslâmî, Beyrut, Birinci Bask1, 1994, IV, 417; V, 386; VIII, 251; XIII, 307. Şâfîi kaynağı için bk. Râfîi, Ebü’l-Kāsım Abdülkerîm b. Muhammed b. Abdilkerîm er-Râfî̂ el-Kazvînî, Fethü'l-'Azîz bi Şerhi'l-Vecîz, Dârü’l-Fikr, y.y t.y, II, 152. Hanbeli kaynakları için bk. İbn Kudâme, el-Muğnî, I, 20; Abdurrahman b. İbrahim b. Ahmed Bahâüddîn el-Makdisî, el- 'Udde Şerhü'l- 'Ümde, Dârü'l-Hadîs, Kahire, 2003, 23.

${ }^{61}$ İbnü's-Salâh, Fetâvâ İbnü's-Salâh, tahk. Muvaffak Abdullah Abdulkadir, Mektebetü'l-'Ulûm ve'l-Hikem, Beyrut, h.1407, 7.

62 Örneğin bir hadisin kaynağı olarak Ebû Davud, Tirmizî, Nesâî, İbn Mâce vermektedir. Hemen sonra da Tirmizî’nin hadis hakkında "hasen ve sahih"tir yorumuna yer verir. Şerhu Müşkili'l-Vasît, tahk. Abdülmün'im Halîfe Ahmed Bilâl, Dârü’l-Künûz, Suudi Arabistan 2011, II, 40. 
görülmektedir. ${ }^{63} \mathrm{O}$ aynı zamanda muhaddis kimliğine uygun bir şekilde fıkıh eserinde hadisleri işlemektedir. Nevevî Mecmû'daki gibi yoğun olmasa da Ravdâtü't-Tâlibîn adlı eserinde de hadis kaynaklarına referansta bulunmakta; muhaddislerin hadisler hakkındaki yorumlarını zikretmektedir. Bunun sebebi Mecmû' ile Ravdâ eserlerinin özelliklerinden kaynaklanmaktadır. Mecmû' şerh olması hasebiyle her açıdan detaylandırma amacı bulunmaktadır. Ravzâ ise Rafi'i'nin Fethü'l-'Azîz adlı eserin muhtasarı olması hasebiyle hadis tahriçlerine yer vermesi kitabı amacının dışına çıkarabileceğinden, Nevevî bundan olabildiğince kaçınmıştır diyebiliriz. Aynı şekilde bu dönem Hanbelî kaynaklarında da zikredilen her hadis sonrasında hadisin geçtiği temel hadis kaynakları ve hadis hakkındaki yorumlara (hasen, sahih, zayıf gibi) yer verildiğini görmekteyiz. ${ }^{64}$ Hanbeli fikıh kaynakları eğer hadis Buhârî ve Müslim'in ortak rivâyeti ise genelde hadisten sonra "müttefekün aleyh" ibaresi ile bazen "Sahîhayn" ifadesi ile kaynağını zikretmektedirler. ${ }^{65}$

Hicrî yedinci asır fikıh eserlerinde Kütüb-i Sitte başta olmak üzere hadis kaynaklarının referansının yaygınlaşıp kabul gördüğünü söyleyebiliriz. Kütüb-i Sitte içerisinde olmamasına rağmen hicrî beşinci asırdan itibâren Dârekutnî’ye referans yapıldığını; Ebû Dâvûd'un süneninin hicrî dördüncü ve beşinci asırda diğer hadis kaynaklarına göre daha fazla referans gösterildiğini görmekteyiz. Nitekim Dinçoğlu, Ebû Davud'un Sünen'i hakkında Hattabî'nin (ö. 388/998) şu şu değerlendirmesini aktarır: "Henüz dini ilimlerde Ebu Davud'un Sünen'i gibi değerli bir kitap tasnif edilmiş değildir. (Sünen), halk arasında kabul görmüş ve mezheplerindeki ihtilaflarından (dolayl) fakihler ve ulemâ arasında hakem olmuştur. Sünen, Irak, Mısır, Mağrip ve yeryüzündeki birçok bölgedeki ilim adamının kendisi için bir şeyler bulabildiği ve hadis musanniflerine de örnek (bir eserdir.)"66 Hattabî'nin bu değerlendirmesi hicrî dördüncü asır ve sonraki asırlarda fakihlerin Ebû Dâvûd'a olan ilgisinin sebebini açıklamaktadır.

\section{Temel Hadis Kaynaklarının Mezhep İçi Fıkhî Tercihlerde Referans Kaynă̆ı Olması}

Hicrî dördüncü asırdan itibâren fikıh eserlerinde temel hadis kaynaklarının referans gösterilmesinin gerekçelerinden biri de farklılaşan mezhep içi görüşlerin tercih edilmesinde ölçüt olarak kullanılmasıdır. Konuyla alakalı olarak Hanefî̀ ve

${ }^{63}$ Buhârî, Müslim, İbn Mâce, Ebû Davud, Tirmizî, Nesâî’ye bir tek sayfada yaptığı referansa örnek için bk. Nevevî, el-Mecmû', IV, 17.

${ }^{64}$ Örneğin İbn Kudâme, zikrettiği bir hadisin Müslim, Ebû Davud ve Nesâî tarafindan rivayet edildiğini; hemen sonra zikrettiği hadisin müttefekün aleyh olduğunu, akabindeki hadisin yine Ebû Davud, İbn Mâce ve Tirmizi tarafından rivayet edildiğini belirtmektedir. (el-Muğnî, I, 342) Zikrettiği başka bir hadisle alakalı Tirmizî’nin “o sahih ve hasen bir hadistir” şeklindeki görüşüne yer vermektedir. (el-Muğnî, I, 389) Eserin tümüne incelendiğinde benzer yaklaşımın hemen hemen tüm hadisler için yapıldığ 1 görülecektir. Hem hadisin geçtiği hadis kaynakları zikredilmekte hem de muhaddislerin hadis hakkındaki görüşlerine yer verilmektedir.

${ }^{65}$ Müttefekün aleyh ifadesi çokça zikredilmektedir. İbn Kudâme'nin ikisini kullanmasına dair bk. el-Muğnî, I, 29; el-Kâfî fî Fıkhhi'l-İmâmi'l-Ahmed, Dârü'l-kütübi'l-İlmiyye, Birinci Bask1, 1994, I, 17.

${ }^{66}$ Mehmet Dinçoğlu, Ebû Dâvud'un Sünen Adlı Eseri Kaynaklarl ve Tasnif Metodu, Doktora tezi, Ankara Üniversitesi Sosyal Bilimler Enstitüsü, Ankara 2008, 51. Nakil için bk. Hattabî, Ebû Süleymân Hamd (Ahmed) b. Muhammed b. İbrâhîm b. Hattâb, Me 'âlimü's-Sünen, el-Matbaatü'lİlmiyye, Haleb 1932, I, 6. 
Şâfî̂’lerden birer örnek ele alıp, çalışmanın daha fazla uzamaması adına başka örnekleri dipnotta kısaca zikredeceğiz. ${ }^{67}$

\section{Abdeste sakalı hilâllemenin hükmü}

Ebû Hanîfe ve İmam Muhammed'e göre sakalları hilallemek abdestin sünnetlerinden değildir. Onlara göre sakalı hilalleme caiz bir durumdur. Ebû Yusuf ise İbn Ömer'in “ Peygamber abdest aldı̆̆ında sakallarını hilallerdi” rivayeti ile Enes b. Malik'în 'Ben Rasûlullah'ı abdest alırken gördügüumde parmakları bir tarağın dişleri gibi sakalları arasındaydı ve 'Cibrîl bana geldi ve abdest aldı̆̆ımda bana sakallarımı hilâllememi emretti' dedi." rivayetleri sebebi ile sünnet olarak görmektedir. ${ }^{68}$ Kâsânî mezhep imamlarının görüşlerini aktardiktan sonra Peygamber'in abdestini rivayet edenlerin hilalleme yapmadıklarını ve Ebû Yusuf'un görüşüne destek olarak sunduğu rivâyetlerin muvâzebe/devamlılık ifade etmediğini belirterek sünnet olduğu hükmüne katılmaz. ${ }^{69}$

Hanefîlerin metin ve muhtasar eserlerinden olan Muhtasarü'l-Kudûrî ${ }^{70}$, Bidâyetü'l-Mübtedî̀ $^{71}$, el-Muhtâr ${ }^{72}$, Tenvîrü'l-Ebsâr ${ }^{73}$, Kenzü'd-Dekâik $^{74}$, Mültekâ'l-Ebhur ${ }^{75}$ eserlerinde ise sakalı hilallemek abdestin sünnetleri arasında sayılmaktadır. Mültekâ'da bu görüş muhtar olan görüş olarak zikredilmektedir. ${ }^{76}$ İbn Nüceym (ö. 970/1563) ise esah görüş olarak aktarmaktadır. Esah olmasının gerekçesi olarak Ebu Dâvûd'un süneninde Enes'ten rivayet edilen “Rasulüllah abdest aldı̆̆ında avuçlarına su alır ve çenesinin altından sakallarını hilaller ve böyle yapmamı Rabbim emretti derdi" hadisini delil göstermektedir. İbn Nüceym hadisi aktarırken Ebu Dâvûd'un hadis hakkında sessiz kaldığını belirtir. ${ }^{77}$ İbn Âbidîn (ö.1252/1836), İbn Nüceym'in aktarımda geçen Ebû Dâvûd'un hadisi

67 Şâfîi mezhebinde yağı süzülmeden kurutulmuş yoğurdun (الأقط) fitır zekâtına konu olup olmadığı, akşam namazından önce iki rekat namazın müstehab olup olmadığıyla alakalı meselelerde de Nevevî, Buhârî ve Müslim gibi hadis kaynaklarında geçen sahih haberler nedeniyle mezhepteki görüşlerden birini tercih emiştir. Yağı süzülmeden kurutulmuş yoğurdun (الأقط) fitır zekatı için bk. Nevevî, Minhâc, II, 117; Şemsüddîn Muhammed b. Ahmed el-Hatîb eş-Şirbînî elKâhirî, Muğnî'l-Muhtâc, Dârü'l-Kütübi'l-İlmiyye, 1. Bask1, y.y 1994, II, 117. Akşam namazından önce iki rekat namazın müstehablığıyla ilgili bk. Nevevî, Ravdatü't-Tâlibîn, el-Mektebü'l-İslâmî, 2. Bask1, Beyrut/Dımaşk/Amman 1991, I, 327.

${ }^{68} \mathrm{Bk}$. Serahsî, el-Mebsût, I, 80.

${ }^{69}$ Kâsânî, Bedâ 'i' 'ü's-Sanâ 'i, I, 23.

${ }^{70}$ Ahmed b. Muhammed b. Ahmed b. Cafer b. Hemedan Ebü'l-Hüseyn el-Kudûrî, Muhtasarü'lKudûrî, thk. Kamil Muhammed Uveyde, Dârü'l-Kütübi'l-İlmiyye, Birinci Bask1, y.y 1997, 11.

${ }^{71}$ Ebû'l-Hasan Burhânüddîn el-Merğinânî, Metnu Bidâyeti'l-Mübtedî, Mektebetu ve Matbaatu Muhammed Ali Sabah, t.y Kahire, 3.

72 Abdullah b. Mahmud b. Mevdûd el-Mevsılî, el-Muhtâr, Tekin Kitabevi, Konya, 2014, 19.

73 Şihâbüddîn (Şemsüddîn) Muhammed b. Abdillâh b. Ahmed el-Ömerî et-Timurtâşî el-Gazzî, Tenvîri'l-Ebsâr ve Câmi 'u'l-Bihâr, tashih Kemâlüddîn Mücahid el-Ezherî, 1. Bask1, Matbaatü'tTerekkî, Misır t.y., 3.

${ }^{74}$ Ebû'l-Berkât Abdullah b. Ahmed b. Mahmud Hâfıüddîn en-Nesefî, Kenzü'd-Dekâik, thk. Saîd Bekdâş, Dârü'l-Beşâiri'l-İslâmiyye, Birinci Bask1, 2011, 139.

75 İbrahim b. Muhammed b. İbrahim el-Halebî, Mültekâ'l-Ebhur, Dersaâdet h.1303, Yasin yayınevi İstanbul 2005, 6.

${ }^{76}$ Halebî, Mültekâ, 6.

${ }^{77}$ Zeynuddîn b. İbrahim b. Muhammed el-Mısrî, el-Bahrü'r-Râik Şerhu Kenzi'd-Dekâik, Dârü'lKütübi'l-İslâmî, İkinci Baskı, t.y y.y, I, 22-23. 
rivayet ettikten sonra sukut etmesinin Ebû Dâvûd açısından hasen hadis görülmesi anlamına geldiğini belirtir. ${ }^{78}$ Aynî de Ebû Davud'un hadis konusunda suskun kalmasını hadisi kabul ettiği anlamına geldiğini ifade ederek muarızlarına karşı Ebû Dâvud'u ve Hâkim'in Müstedrek'inde daha başka tariklerle hadisin sika râvilerle rivâyet edilmesini delil olarak ileri sürer. ${ }^{79}$

Aynî de sakalı hilallemenin sünnet olduğu hükmüne katılmaktadır. Bu konuda en önemli argümanları konuyla ilgili rivayet edilen hadis ve sahabe kavlidir. ${ }^{80} \mathrm{O}$ mezhep içinde sünnet olmadığını dile getiren Kâkî ve Serucî gibi fakihleri ise konuya dair rivâyetlere muttali olmama ile suçlamaktadır. Serucî'ye yönelik olarak "Onun hadis kitaplarına muttali olmaması, söz konusu hadislerin mevcut olmamasını gerektirmez" ifadesi ile Ahmed b. Hanbel ve İbn Ebî Hâtim'in konuya dair sahih hadis olmadığına dâir iddialarına Tirmizî’de geçen rivâyeti delil göstermektedir. ${ }^{81}$

Hanefî mezhebinde fetva, meseleye ve üç imamın ittifaklarına göre farklılaşmaktadır. İbadetler konusunda Ebû Hanîfe'nin görüşü tercih edilirken, ${ }^{82}$ Ebû Hanîfe'nin diğer iki imamdan biri ile hemfikir olduğu görüş, diğer imamın tek başına kaldığı görüşe tercih edilir. ${ }^{83}$ Burada konu hem ibadetler olmasına; hem de tarafeyn'in üzerinde hemfikir olduğu hüküm olmasına rağmen Ebû Yusuf'un görüşü sonraki Hanefi fukahâsınca tercih edilmiştir. Karadağ, Aynî’nin konu hakkındaki görüşü ile ilgili değerlendirme yaparken haklı olarak Aynî'nin tercih ettiği görüşün Ebû Yusuf'un görüşü olmasına rağmen buna değinmemesini veya açıkça bunu belirtmemesini dikkat çekici olarak görmektedir. ${ }^{84}$ Mezhep içerisinde Kâsânî'den sonra bu görüş değişiminin sebebi hicrî altıncı asrın sonları ile yedinci asrın başlarında kendini iyice hissettiren hadis üstünlüğüne bağlayabiliriz. Nitekim bu dönem Kütüb-i Sitte eserlerinin fikıh kaynaklarında mûteber birer hadis kaynakları olarak başvurulduğu bir döneme rastlar.

\section{Oruç kazası olduğu halde ölen kimse yerine fidye vermek veya oruç tutmak}

Üzerinde vacip oruç borcu olduğu halde ölen kimsenin tutmadığı oruçlar yerine fidye veya başka birinin oruç tutması seçeneklerinden hangisinin daha iyi olduğu meselesi hakkında Şâfiî’den iki görüş aktarılmaktadır. Şâfiî’nin kadim görüşüne

\footnotetext{
${ }^{78}$ İbn Abidin, Minhatü 'l-Hâlik (Bahrü'r-Râik Şerhu Kenzi'd-Dekâik ile beraber), Dârü'l-Kütübi'lİslâmî, İkinci Baskı, t.y. y.y., I, 22.

${ }^{79}$ Ebû Muhammed (Ebü's-Senâ) Bedrüddîn Mahmûd b. Ahmed b. Mûsâ b. Ahmed el-Aynî, elBinâye Şerhü'l-Hidâye, Dârü'l-Kütübi'l-İlmiyye, Lübnan 2000, I, 222.

${ }^{80}$ Bekir Karadağ, Bedruddîn Aynînin Fıkıhçılı̆̆ , Basılmamış Doktora Tezi, Dicle Üniversitesi Sosyal Bilimler Enstitüsü, Diyarbakır 2016, 203.

${ }^{81}$ Karadağ, Bedruddîn Aynînin Fıkıhçılı̆̆ı, 203; Aynî, el-Binâye, I, 225-226.

82 Yusuf Eşit, İbn Abidin'in "Şerhu Ukûdi Resmi'l-Müftî”" Adll Eseri Ve Bu Eser Işı̆̆ı̆nda Müftünün Mezhep İçi Farklı Görüşler Karşısındaki Durumu, Basılmamış Yüksek Lisans Tezi, Erciyes Üniversitesi Sosyal Bilimler Enstitüsü, Kayseri 2009, 110; İbn Âbidîn, Şerhu Ukûdi Resmi'l-Müftî, İkinci Bask1, Merkezu Tev'iyeti F1khi’l-İslamî, Haydarabâd, h.1422, 29-30.

${ }^{83}$ Eşit, İbn Abidin'in "Şerhu Ukûdi Resmi'l-Müftî” Adlı Eseri, 121; Şeyhzade Abdurrahman b. Muhammed, Mecmeu'l-Enhur fí Serhi Mültekâ'l-Ebhur, İstanbul, 1311, I, 70.

${ }^{84}$ Karadă̆, Bedruddîn Aynînin Fıkıhçılı̆̆ı, 203.
} 
göre ölenin velisi "üzerinde oruç borcu olduğu halde ölen kimse yerine velisi oruç tutar" hadisince onun yerine oruç tutar. Cedid görüşüne göre ise fidye verir. ${ }^{85}$

Nevevî; hadis konusunda muhakkik olanlara göre kadim görüşün sahih olduğunu ifade etmektedir. O, kadim görüşü destekleyen hadisleri zikredip, cedid görüşün dayanağı olan hadisler ile alakalı muhaddislerin görüşlerini aktardıktan sonra Beyhakî'nin velinin oruç tutabileceğine dair rivayetler ile alakalı şu değerlendirmesine yer verir: "Merfû' hadisler isnâd açısından daha sahih, râvi açısından daha meşhurdur. Hem bu hadislere Sahîheyn'in iki yazarı da kitaplarında yer vermiştir. Şayet Şâfiî hadisin tüm tariklerine ve benzerlerine vâkıf olsaydı onlara (orucu ihtiva eden hadislere) muhalefet etmezdi." Beyhakî'nin bu değerlendirmesinden sonra kendisi şu yorumu yapar: "Benim görüşüm, ölen kimsenin velisinin onun yerine ramazan ve adak gibi diğer (tutması gerekip de tutmadiğı) vacip oruçları tutmasının bahsi geçen (ve) muârızı olmayan sahih hadislerden ötürü caiz olmasıdır. Bu (görüss), Şâfî̀'nin 'Sahih hadis benim mezhebimdir. Ona muhalif olan görüşümü terk ediniz.' sözü gereği onun mezhebi (görüşü) olmalıdır ... Şâfî̀ daha önce geçtiği üzere İbn Abbâs'tan rivayet edilen hadisin ancak bazl tariklerine vaklf olmuştur. Şayet tüm tariklerine, Büreyde ve Âş̧e'nin Peygamberden aktardıklarl hadise vâkıf olsaydı buna muhalefet etmezdi."

Görüldüğü üzere Beyhakî görüşünü dayandırdığg hadislerin sıhhatini desteklemek babından Sahîhayn'ı kıstas olarak kullanmaktadır. Beyhakî'nin hadis kaynaklı ifade ettiği görüş hicrî V. ve VI. asırda rağbet görmemiştir. Çünkü hicrî V. ve VI. asır Şâfiî fikıh kaynaklarında Şâfiî’nin cedid görüşü benimsenmiştir. ${ }^{87}$ Öyle ki Cüveynî Şâfî̂'nin cedid görüşünde haberle ameli terkettiğine (haber olmasına rağmen onunla amel etmemesine) dâir bir bilgiye sahip olmadığını; haberi terk etmesinin ancak haberin zayıflığına veya neshine dair bir bilgisi olmasından ötürü olduğunu belirtir. ${ }^{88} \mathrm{Bu}$ yaklaşım mezhebin kurucu imamının hadis konusundaki otoritesine güven anlamına gelmektedir.

Beyhakî ile aynı asırda yaşamış olan Mâverdî, Cüveynî ve Şîrâzî, Beyhakî’nin aksine cedid görüşü benimsemişlerdir. Beyhakî'nin hadis merkezli açılımı ancak hicrî yedinci asırda İbn Salâh ve Nevevî gibi aynı zamanda iyi birer muhaddis olan fakihlerce kabul görmüştür. İbn Salâh Müslim'de geçen sahih hadisten ötürü kadim görüşün sahih olduğunu belirtmektedir. ${ }^{89}$ Daha sonra Nevevî de hadis kaynaklarını referans göstererek bu görüşü temellendirmeye çalışmıştır. O bunu yaparken mezhep imamın otoritesine bağlılı̆̆ını ilan etmek veya bu tavrının

\footnotetext{
${ }^{85}$ Mâverdî, İmam Şâfîi’nin hem kadim hem de cedid görüşüne göre oruç tutulmayacağı şeklinde olduğunu; Ancak kimi fakihlerin "oruç tutulabilir" şeklindeki görüşü kadim görüş olarak imama nispet ettiklerini belirtir. (el-Hâvi’l-Kebir, III, 453)

${ }^{86}$ Nevevî, el-Mecmû' Şerhü'l-Mühezzeb, VI, 368-370.

${ }^{87}$ Bk. Mâverdî, el-Hâvi’l-Kebir, III, 453; Ebû İshâk Cemâlüddîn İbrâhîm b. Alî b. Yûsuf eşŞîrâzî,, el-Mühezzeb fi Flkhi 'ş-Şâfi ‘î, Dârü'l-Kütübi'l-İlmiyye, y.y t.y, I, 344; Cüveynî, Nihâyetü'lMatlab, IV, 62; XVIII, 322; Ebû Bekr Fahrü'l-islâm Muhammed b. Ahmed b. el-Hüseyn eş-Şâşî, Hilyetü'l-'Ulemâ fi Ma'rifeti Mezâhibi'l-Fukahâ, tahk. Yasin Ahmed İbrahim Dradeke, Müessesetü'r-Risâle/Dârü'l-Erkâm, Beyrut/Amman 1980, III, 175; İmrânî, el-Beyân, III, 546.

${ }^{88}$ Cüveynî, Nihâyetü'l-Matlab, IV, 62.

${ }^{89}$ İbn Salâh, Fetâvâ İbnü's-Salâh, 227.
} 
mezhep kurallarına uygun oluşunu beyan etmek adına "hadis sahihse benim mezhebim odur" şeklinde Şâfîi’den aktarılan sözüne sarılmaktadır. Bu yaklaşım sonraki kimi Şâfîi fakihleri nezdinde de benimsenmesinde etkili olmuştur. ${ }^{90}$

\section{Temel Hadis Kaynaklarının Mezhep İmamının Görüşünün Terkedilmesinde Referans Kaynağı Olarak Kullanılması}

Temel hadis kaynakları savunula gelen mezhep görüşünün veya mezhep imamının görüşünün dişında bir görüşün benimsenmesinde de etkili olmuştur. Aşağıda Hanefî, Malikî ve Şâfiî mezheplerinde tespit ettiğimiz birer örnek zikredeceğiz.

\subsection{Hanefî̀ Mezhebi}

\section{Küsuf Namazında Hutbe}

Hanefîler küsuf namazında hutbenin olmadığı görüşündedirler. ${ }^{91}$ Hanefî fakihler konu hakkında nakil olmamasından ötürü küsuf namazında hutbenin olmadığını belirmektedirler. Şâfiîlerin, hutbenin müstehab olduğuna dâir kendi görüşlerine dayanak olarak zikrettikleri Hz. Ayşe'den rivayet edilen hadisi ise dua etmek veya o dönemde insanların güneş tutulmasını Hz. İbrahim'in vefatına bağladıklarına dâir olan inançlarının yanlışlığını belirtmek üzere olan bir konuşma olduğu şeklinde yorumlarlar. ${ }^{92}$ Bâbertî (ö.786/1384), söz konusu yorumun, aktarılan hadisin sahih olması durumunda yapıldığını belirtir. Ona göre böyle bir hadis nakledilmemiştir. Dolayısıyla bu durum (hutbe okuma fiili) yaşanmamıştır. ${ }^{93}$

Aynî ise bu görüşe katılmaz. Konuyla alakalı naklin olmadığına yönelik Hanefî fakihlerinin görüşlerine karşı çıkar. O, Buhârî ile Müslim'in rivayet ettikleri hadisleri $^{94}$ Müslim'in Cabir'den rivayeti ve Ahmed b. Hanbel'in Semüre b. Cündeb'den rivâyetini kendi görüşüne destek olarak zikreder. ${ }^{95}$ Aynî, Hanefî fakihlerin var olan rivâyeti te'vil etmeye kalkışmalarını naklin olduğuna dair bir itiraf olarak kabul eder. Ancak onların yorumlarını tutarlı bulmaz. Hz. Peygamber'in minbere çıktığına dair yine Ahmed b. Hanbel, Nesâ̂, İbn Hibbân'da aktarılan rivâyetleri zikredip hutbenin maksadının muayyen bir şeye hasredilemeyeceğini ifade eder. ${ }^{96}$ Görüldüğü üzere Aynî hadis kaynaklarında

${ }^{90}$ Bk. Şirbînî, Sahîhayn'da geçen sahih haberler gibi haberlerin delalet etmesi sebebiyle kadim görüşün müfta bih ve azhar olduğunu belirtir.(el-İkna' fi Halli Elfâzi Ebî Şüca', Dârü'l-Fikir, Beyrut, t.y, I, 242).

91 Semerkandî, Tuhfetü'l-Fukahâ, Darü'l-Kütübi'l-İlmiyye, İkinci Bask1, Beyrut 1994, 183; Kudûrî, Muhtasarül-Kudurî, 43; Merğînânî, el-Bidâye, 28; Mevs1lî, el-Muhtâr, 32.

92 Kasânî, Bedâiu's-Sana ‘i, I, 282.

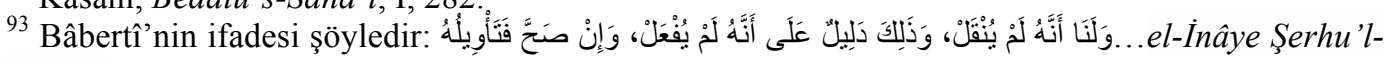
Hidâye, Dârü'l-Fikr, y.y t.y, 90.

${ }^{94}$ Esma'dan rivayet etikleri hadis şöyledir: “...Güneş ve Ay ortaya çıktıktan sonra Rasûlullah (a.v.), ayağa kalktı ve insanlara hitap ederek; Allah'a hamdu senada bulundu ve şöyle dedi: "Güneş ve Ay, Allah'ın iki ayetidir. Ne kimsenin hayatı ne de kimsenin ölümü için batarlar. Ancak Allah, bununla kulları korkutur. Ben, şu durduğum yerde cennet ve cehennemi gördüm. Bana sizin kabrinizde ve yakında Deccalın fitnesiyle imtihan edileceğiniz vahy edildi." Buhârî, "Cum'a", 29; Müslim, "Küsûf", 11; Aynî, el-Binâye, III, 147-148; Karadağ, Bedruddîn Aynînin Fıkıhçılı̆̆ı, 160.

95 Aynî, el-Binâye, III, 148.

${ }^{96}$ Aynî, el-Binâye, III, 149. 
geçen rivayetleri delil gösterip kendi mezhebinde kabul görmüş bir görüşten ayrilmaktadır. $^{97}$

\subsection{Malikî Mezhebi}

\section{Irak Tarafından Gelenlerin Mikatı}

Malikî mezhebinde Irak yönünden gelenlerin mîkatını belirleyenin kim olduğuyla alakalı ihtilaf bulunmaktadır. ${ }^{98}$ Mâlik, Müdevvene'de Hz. Ömer'in Zâtü Irk'1 Irak ehli için mîkat olarak belirlediğini belirtir. ${ }^{99}$ Ancak Hattâb er-Ruaynî (ö.954) Mâlik'in el-Muvatta'da kimin belirlediğini zikretmediğini ifade eder. Ona göre Sahih olan görüş, Hz. Peygamber'in belirlediği şeklindeki görüştür. Kendi görüşüne delil olarak Müslim'de geçen Ebû Zübeyr'den rivayet edilen bir hadisi ileri sürmektedir. Bu hadise yönelik Nevevî'nin yönelttiği tenkide karşı Ebû Dâvûd ve Nesâî'nin Hz. Ayşe'den gelen 'Irak ehli için Zâtü Irk'1 mîkat olarak belirledi" rivâyetini ve İbn Cemâa'nın söz konusu rivâyetin senedi hakkında sahih olduğuna yönelik değerlendirmesini aktarmaktadır. ${ }^{100}$

Ruaynî Irak tarafından gelenlerin mîkatının kimin tarafından belirlediğine yönelik mezhebin kurucu İmamı olan Mâlik'in Müddevene'deki görüşüne rağmen hadis kaynaklarında geçen hadisleri gerekçe göstererek farklı bir görüş benimsemektedir. Ancak bunu yaparken mezhep imamının otoritesi ile hadis kaynakları arasında bir ayrım yapmaz. O mezhep imamının bu konuda fikir beyan etmemesine sığınıp hadis kaynaklarını değerlendirmektedir. Böylece mezhep imamina muhalefet tenkidinden kurtulmak istemektedir.

\section{3. Şâfiî Mezhebi}

\section{Hayvanın Kıble İçin Sütre Olması Meselesi}

Nevevî, Şâfî̂’nin Buveytî'de (Muhtasar'ında) geçen kadın ve hayvanların kıble için sütre olarak kullanılamayacağı şeklindeki sözünü aktarır. Sütrenin kadın olması halinde kişinin aklının kadında kalabilmesinden dolayı bu görüşün anlamlı olduğunu söyler. Ancak o hayvanın sütre olması ile alakalı olarak Sahîheyn'da İbn Ömer'in "Peygamber'in yolculukta hayvanını yere serip ona doğru namaz

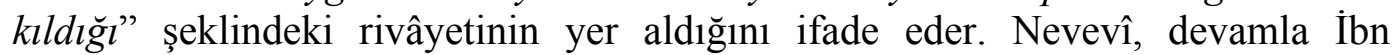
Ömer'in de rivâyete uygun olarak davrandığı bilgisini Buhârî' den aktarır. ${ }^{101} \mathrm{O}$, muârızı olmayan bu sahih hadisin Şâfiî̀'ye muhtemelen ulaşmadığını, dolayısıyla bu hadisle amel edilmesi gerektiği hususunun açığa çıktığını belirtmektedir. Nitekim Şâfî̂ de "hadis sahihse benim mezhebim odur" demiştir. ${ }^{102}$ Görüldüğü

\footnotetext{
97 Muhaddis Hanefi fakihlerden Bedruddîn Aynî’nin hadisle istidlali için bk. Bekir Karadağ, "Bedruddin Aynî̀nin "el-Binâye Şerhu'l-Hidâye" Adlı Eserinde Hadisle İstidlâl Metodu", Anemon: Muş Alparslan Üniversitesi Sosyal Bilimler Dergisi, 2016, Cilt: IV, Say1: 1, s. 201-224.

98 Ebû'l-Velîd Muhammed b. Ahmed b. Muhammed b. Ahmed b. Rüşd el-Kurtubî, Bidâyetü'lMüctehid ve Nihâyetü'l-Muktesid, Dârü'l-Hadis, Kahire, 2004, II, 89.

99 Ebû Saîd Abdüsselâm b. Saîd b. Habîb et-Tenûhî, el-Müdevvene, Dârü'l-Kütübi'l-İlmiyye, Birinci Bask1, 1994, I, 405.

100 Şemsuddin Ebû Abdillah Muhammed b. Muhammed b. Abdurrahman er-Ruâynî et-Trablusî, Mevâhibü'l-Celîl fi Şerhi Muhtasari Halîl, Üçüncü Bask1, Dârü'l-Fikr, y.y 1992, III, 32.

${ }^{101}$ Nevevî, el-Mecmû', III, 248.

102 Nevevî, el-Mecmû', III, 248.
} 
üzere Nevevî mezhebin kurucu imamının bir görüşünü temel hadis kaynaklarında geçen bir hadisi delil göstererek terk etmiştir.

\section{Sonuç}

Sünnetin hüküm verirken başvurulması gereken aslî kaynaklardan olması hasebiyle fukahâ hadisle ilk dönemlerden itibaren iştigal etmiştir. Onlar kendi havzalarındaki rivâyet kaynaklarından gelen ve kendi metodolojilerine uygun diğer havzalardaki hadislerle amel etmişlerdir. İlimlerin teşekkülünden sonraki süreçte özelikle hicrî dördüncü asırda İslam âleminde değer kazanan hadis kaynaklarına fakihler de kayıtsız kalmamışlardır. Bu asırdaki ulaşabildiğimiz Hanefî̀ ve Hanbelî fıkıh eserlerinde Ebû Dâvûd'a atıflar yapıldığını görmekteyiz. $\mathrm{Bu}$ husus, Kütüb-i Sitte dediğimiz güvenilir hadis kaynaklarının tasnif edildiği üçüncü asırdan hemen sonraki asırda fakihlerce de referans kaynağı olarak görülmeye başlandığı anlamına gelmektedir. Hicrî beşinci asırda her mezhepte Kütüb-i Sitte'ye atıflar artarak devam etmekle beraber, muhaddisler nezdinde ne Kütüb-i Sitte ne de Kütüb-i Tis'a gibi tasniflerde yer vermedikleri Dârekutnî'ye atıfların Ebû Davud'tan sonra neredeyse ikinci bir hadis başvuru kaynağı olarak karşımıza çıkmaktadır. Ne var ki ne bu asırda ne de altıncı asırda Kütüb-i Sitte içerisinde sayılan İbn Mâce'ye referansın yapıldığını tespit edemedik. İbn Mâce'ye ancak hicrî yedinci asırda referansların yapıldığını tespit edebildik. Hicrî yedinci asır, aynı zamanda fikıh kaynaklarında geçen hadislerin hadis kaynaklarından tahrîcinin yoğun olarak yapıldığı; muhaddislerin hadisler ile alakalı değerlendirmelerinin fikı eserlerinde yer almasının yaygınlık kazandığı bir dönemdir. İlk dönem fikıh eserlerinde genellikle mezhebin metodik süzgecinden geçmiş ve mezhep imamının onayını almış hadisler yer almaktaydı. Buna karşın H.VII asırda fikıh eserleri neredeyse zikrettikleri hadislerin tümünü temel hadis kaynaklarından tahrîcini yaparak muhaddislerin söz konusu hadis hakkındaki yorumlarını zikretme gereği duymuşlardır. Söz konusu bu gereklilik ehli hadisin sosyo-politik alandaki etkisinden kaynaklandığını söyleyebiliriz.

Fakihler kendi görüşlerinin te'yîdi, muârızların görüşlerinin tenkîdi gibi sebeplerle hadis kaynaklarına başvurmuşlardır. Bunun yanında hadis kaynakları mezhep içi görüşün tercihinde, mezhep imamının görüşünün terkedilmesinde, mezhebe aykırı bir görüşün benimsenmesinde etkili olduklarını söyleyebiliriz. Bu hususların mezhep fakihleri üzerinde bireysel mi, dönemsel mi veya bölgesel mi olduğunun ancak çok daha detaylı bir araştırma ile ortaya çıkacağı kanaatindeyiz. Kütüb-i Sitte gibi güvenilir hadis kaynaklarının fikıh edebiyatı yazımı başta olmak üzere mezheplere etkisi ayrıntılı bir şekilde araştırmayı bekleyen bir husustur. Bunun diğer İslâmî ilimler üzerinde de ne gibi bir etki yaptığı hususu da bu bağlamda önem arz etmektedir.

\section{Kaynakça}

BABERTÎ, Ekmelüddîn Muhammed b. Mahmûd b. Ahmed el-Bâbertî er-Rûmî elMisrî, el-İnaye Şerhu'l-Hidaye, Dârü'l-Fikr, y.y t.y.

BAĞCI, Musa, Hadis Tarihi H. Illk $\ddot{U} c ̧$ Asır, Ankara Okulu Yayınları, Ankara, 2009.

BAHÂÜDDÎN EL-MAKDİSî, Abdurrahman b. İbrahim b. Ahmed, el-'Udde Şerhü'l- 'Ümde, Dârü'l-Hadîs, Kahire, 2003 
CESSÂS, Ebû Bekr Ahmed b. Alî er-Râzî, Şerhu Muhtasari't-Tahavi, Dârü'lBeşâirü'l-İslâmiye/Dârü's-Sirâc, Birinci Baskı, 2010.

CÜVEYNÎ, İmâmü'l-Haremeyn Ebü'l-Meâlî Rüknüddîn Abdülmelik b. Abdillâh b. Yûsuf et-Tâî en-Nîsâbûrî, Nihâyetü'l-Matlab fi Dirâyeti'il-Mezheb, tahk. Abdülazim Mahmud e'd-Dîb, Dârü'l-Menahîc, Birinci Baskı, y.y 2007.

DİNÇOĞLU, Mehmet, Ebû Dâvud'un Sünen Adlı Eseri Kaynakları ve Tasnif Metodu, Doktora tezi, Ankara Üniversitesi Sosyal Bilimler Enstitüsü, Ankara 2008.

EBÛ ALİ EL-HÂŞİî, Muhammed b. Ahmed b. Ebî Musa, el-İrşâd ilâ Sebili'rReşâd, tahk. Abdullah b. Abdullah el-Muhsin et-Türkî, Müessesetü'r-Risâle, y.y. t.y.

EL-BAĞDÂDÎ, Ebû Bekir Ahmed b. Muhammed b. Hârûn b. Yezid, el-Vukîf ve't-Tereccül min'el-Câmi ‘i li Mesâili'l-İmam Ahmed b. Hanbel, Tahk. Seyid Kesrevi Hasan, Dârü'l-Kütübi'l-İlmiyye, Birinci Bask1, 1994.

EBÛ DAVUD, Süleyman b. el-Eş'as b. İshak b. Beşir b. Şeddâd b. Ömer esSicistânî el-Ezdî, Mesâilü'l-İmam Ahmed b. Hanbel Rivayetü Davud es-Sicistânî, tahk. Ebû Muaz Tarık, Mektebetu İbn Teymiye, Mısır 1999.

EBÛ YA'LÂ EL-FERRÂ, Ebû Ya'lâ Muhammed b. el-Hüseyn b. Muhammed b. Halef el-Ferrâ', el-Mesâilü'l-Fikhiyye mik kitâbi'r-Rivâyeteynî ve'l-Vecheynî, thak. Abdülkerim b. Muhammed, Mektebetü'l-Me'arif, Riyâd 1985

,et-Ta 'liketü'l-Kebir fi'l-mesâili'l-Hilâf ala Mezhebi Ahmed,

Dârü'n-Nevâdir, 1. Baskı, y.y.

EL-HAZRECÎ, Cemâlüdîn Ebû Muhammed Ali b. Ebî Yahya Zekeriya b. Mes‘ud el-Ensârî, el-Lübâb fî̀l-Cem 'i Beyne's-Sünneti ve'l-Kitâb, tahk. Muhammed Fadl Abdülaziz el-Murâd, Dârü'l-Kâlem, Sûriye 1994.

ENSÂRÎ, Fethü'l-Vehhâb bi Şerhi Menheci't-Tüllâb, Dârü'l-Fikir, 1994.

EŞİT, Yusuf, İbn Abidin'in "Şerhu Ukûdi Resmi'l-Müftî” Adlı Eseri Ve Bu Eser Işı̆̆ııda Müftünün Mezhep İçi Farklı Görüşler Karşısındaki Durumu, Basılmamış Yüksek Lisans Tezi, Erciyes Üniversitesi Sosyal Bilimler Enstitüsü, Kayseri 2009.

GAZZÂLÎ, Ebu hamid Muhammed, el-Mustasfâ, tahk. Muhammed Abdüsselam Abdü'ş-Şâfiî, Dârü'l-Kütübi'l-İlmiyye, 1993. el-Vasît fi'l-Mezheb, Dârü's-Selâm, Birinci Baskı, Kahire, h.1417.

HALEBÎ, İbrahim b. Muhammed b. İbrahim, Mültekâ'l-Ebhur, Derseaadet h.1303, Yain yayınevi İstanbul 2005.

SÂLİH B. AHMED B. HANBEL, Ebü'l-Fazl Sâlih b. Ahmed b. Muhammed b. Hanbel eş-Şeybânî, Mesâilü'l-Imam Ahmed b. Hanbel Rivayetü İbn Ebî el-Fadl Salih, Dârü'l-İlmiyye, Hindistan, t.y.

HARAKÎ, Ebûl-Kasım Ömer b. El-Hüseyin b. Abdullah, Metnü'l-Harakî, Dârü'sSahabe li't-Türâs, y.y. 1993. 
HATTABÎ, Ebû Süleymân Hamd (Ahmed) b. Muhammed b. İbrâhîm b. Hattâb, Me 'alimü's-Sünen, el-Matbaatü'l-İlmiyye, Haleb 1932.

İBN ABIDIIN, Minhetü'l-Halik, Bahrü'r-Râik Şerhu Kenzi'd-Dekâik ile beraber, Dârü'l-Kütübi'l-İslâmî, İkinci Bask1, t.y. y.y.

İBN EMÎRU HÂC EL-HALEBÎ, Ebû Abdillâh Şemsüddîn Muhammed b. Muhammed b. Muhammed el-Halebî, et-Taķrîr ve't-Tahbîr, Dârü'l-Kütübi'lİlmiyye, 1983.

İBN KUDÂME, Ebû Muhammed Muvaffaku'd-Din Abdullah b. Ahmed b. Muhammed el-Makdisî, el-Mŭgnî li İbni Kudâme, Mektebetul-Kâhire, y.y, t.y, 1968

, el-Kâfî fî Fıkhhi'l-İmâmi'l- Ahmed, Dârü'l-kütübi'l-İlmiyye, Birinci Bask1, 1994.

İBN KUDÂME, Ebû Muhammed Muvaffakuddîn Abdullāh b. Ahmed b. Muhammed b. Kudâme el-Cemmâîlî el-Makdisî, el-Muğnî li İbni Kudâme, Mektebetü'l-Kahire, y.y 1968.

İBN MÜFLİH, Ebû Abdillâh Şemsüddîn Muhammed b. Müflih b. Muhammed elMakdisî er-Râmînî, Kitâbü'l-Furu', tahk. Abdullah b. Abdullah el-Muhsin etTürkî, Müessesetü'r-Risâle, 2003.

İBN NÜCEYM, Zeynuddin b. İbrahim b. Muhammed, Bahrü'r-Râik Şerhu Kenzi'd-Dekâik, Dârü'l-Kütübi'l-İslâmî, İkinci Baskı, t.y y.y.

İBN RÜŞD EL-HAFÎD, Ebü'l-Velîd Muhammed b. Ahmed b. Muhammed elKurtubî, Bidâyetü'l-Müctehid ve Nihâyetü'l-Müktesid, Dârü'l-Hadis, Kahire, 2004.

İBN RÜŞD, Ebü'l-Velîd Muhammed b. Ahmed b. Ahmed el-Kurtubî el-Endelüsî, el-Beyân ve't-Tahsil, tahk. Muhammed Hacî, Dârü'l-Ğarbi'l-İslâmî, Beyrut, 1988.

İBN SALÂH, Ebû Amr Takıyyüddîn Osmân b. Salâhiddîn Abdirrahmân b. Mûsâ eş-Şehrezûrî, Mukkadimetu İbn Salâh (Ma'rifetu 'Envâ'î 'Ulumi'l-Hadîs), tahk. Nuruddin Itr, Beyrut 1986.

Fetâva İbü's-Salâh, tahk. Muvaffak Abdullah Abdulkadir, Mektebetü'l-'Ulûm ve'l-Hikem, Beyrut, h.1407.

,Şerhu Müşkili’l-Vasît, tahk. Abdülmün‘im Halîfe Ahmed Bilâl, Dârü'l-Künûz, Suudi Arabistan 2011.

İMRÂNÎ, Ebû'l-Hüseyn Yahya b. Ebî'l-Hayr b. Sâlim el-Beyan fi Mezhebi'lİmam eş-Şâfî̀, Minhâc, Birinci Baskı, Cidde 2000.

KANDEMİR, M.Yaşar, "Sahîhayn", DİA, İstanbul 2008, XXXV.

KARADAĞ, Bekir, Bedruddîn Aynînin Fıkıhçılı̆̆ı, Basılmamış Doktora Tezi, Dicle Üniversitesi Sosyal Bilimler Enstitüsü, Diyarbakır 2016.

"Bedruddin Aynî̀nin “el-Binâye Şerhu'l-Hidâye” Adlı Eserinde Hadisle İstidlâl Metodu", Anemon: Muş Alparslan Üniversitesi Sosyal Bilimler Dergisi, 2016, Cilt: IV, Sayı: 1, s. 201-224. 
KARÂFî, Ebü'l-Abbâs Şihâbüddîn Ahmed b. İdrîs b. Abdirrahmân el-Misrî, ezZahîre, tahk. Muhammed Hacî ve diğerleri, Dârü'l-Ğarbi'l-İslâmî, Beyrut, Birinci Bask1, 1994.

KÂSÂNÎ, Alâüddîn Ebû Bekr b. Mes'ûd b. Ahmed, Bedâ 'i 'ü’s-Sanâ 'î fi Tertibi'şŞerâi ',Dârü’l-Kütübi'l-İlmiyye, 2. Bask1, y.y 1986.

KALVAZÂNî, Ebü'l-Hattâb Mahfûz b. Ahmed b. el-Hasen, el-Hidâye ale Mezhebi Ahmed, Müessesetu Gürâs li'n-Neşri ve’t-Tevzi‘î, Birinci Baskı, Kuveyt 2004.

KUDÛRÎ, Ebü'l-Hüseyn Ahmed b. Ebî Bekr Muhammed b. Ahmed el-Kudûrî, Muhtasarül-Kudurî, thk. Kamil Muhammed Muhammed Uveyde, Dârü'lKütübi'l-İlmiyye, Birinci Bask1, y.y 1997.

et-Tecrid li'l-Kudûrî, tahk. Muhammed Ahmed Sirâc-Ali Cuma Muhammed, Dârü's-Selâm, Kâhire 2006.

SAHNÛN, Ebû Saîd Abdüsselâm b. Saîd b. Habîb et-Tenûhî, el-Müdevvene, Dârü'l-Kütübil-İlmiyye, Birinci Baskı, 1994.

MÂVERDÎ, Ebu'l-Hasan Ali b. Muhammed b. Habib el-Basrî, el-Hâvi'l-Kebîr fi Fıkhi Mezhebi'l-İmâmi'ş-Şâfî̀, tahk. Ali Muhammed Maavvad-Adil Ahmed Abdü'l-Mevcud, Dârü'l-Kütübi'l-İlmiyye, Beyrut 1999.

MERĞİNÂNÎ, Ebû'l-Hasan Burhâneddün, Metnu Bidâyetil-Mübtedî, Mektebetu ve Matbaatu Muhammed Ali Sabah, t.y Kahire.

MEVSILÎ, Abdullah b. Mahmud b. Mevdûd, el-Muhtâr, Tekin Kitabevi, Konya, 2014.

NESEFÎ, Ebü'l-Berekât Abdullah b. Ahmed b. Mahmud Hafizuddin, Kenzü'dDekâik, İbn Nüceym'in Bahru'r-Râik adlı eserinin içinde, Dârü'l-Kütübi'l-İslâmî, İkinci Baskı, t.y y.y.

NEVEVÎ, Ebu Zekeriya Muhyiddin Yahya b. Şeref, el-Minhâc Şerhu Sahîhi Müslim, Dâru İhyâi't-Türâsi'l-Arabî, Beyrut, h. 1392.

et-Takrîb ve't-Teysîr, tahk. Muhammed Osman, Beyrut, 1985. el-Mecmu' Şerhü'l-Mühezzeb, Dârü'l-Fikr, y.y. t.y..

........,Ravdatü't-Tâlibîn, $\quad$ el-Mektebü'l-İslâmî, $2 . \quad$ Bask1, Beyrut/Dımaşk/Amman 1991.

RÂFî̂, Ebü'l-Kāsım Abdülkerîm b. Muhammed b. Abdilkerîm el-Kazvînî, Fethü'l- 'Aziz bi Şerhi'l-Veciz, Dârü'l-Fikr, y.y. t.y.

RÜYÂNÎ, Şemsuddin Ebû Abdillah Muhammed b. Muhammed b. Abdurrahman et-Trablusî, Mevâhibü'l-Celil fi Şerhi Muhtasari Halil, Üçüncü Baskı, Dârü'lFikr, y.y 1992.

SEM‘ÂNÎ, Ebü'l-Muzaffer Mansûr b. Muhammed b. Abdilcebbâr et-Temîmî elMervezî, Kavâti 'u'l-Edille fi'l-Usûl, tahk. Muhammed Hasan Muhammed Hasan İsmail, Beyrut, 1999. 
el-İstilâm fi'l-Hilâf Beyne'l-İmameyni eş-Şâfî̀ ve Eb̂̂ Hanife, tahk. Nayif b. Nafi' el-Umrî, Dârü'l-Menâr, Birinci Baskı, 1992.

SEMERKANDÎ, Ebû Bekr Alâüddîn Muhammed b. Ahmed b. Ebî Ahmed esSemerkandî Tuhfetü'l-Fukehâ, Dârü'l-Kütübi'l-İlmiyye, Beyrut 1994.

SERAHSÎ, Ebû Bekr Şemsü’l-eimme Muhammed b. Ebî Sehl Ahmed, el-Mebsût, Dârü'l-Marife, Beyrut 1993.

SÜBKÎ, Ebü'l-Hasen Takıyyüddîn Alî b. Abdilkâfî b. Alî b. Temmâm, Ma'nâ Kavli'l-İmâm el-Muttalibî İzâ Sahha'l-Hadîs Fehüve Mezhebi,Dârü'l-Beşâiri'1İslamiyye, Lübnan 1994.

ŞÂFIî, Ebû Abdillâh Muhammed b. İdrîs b. Abbâs eş-Şâfiî,el-Ümm, Dârü’lMarife, Beyrut 1990.

ŞÂŞÎ, Ebû Bekr Fahrü'l-islâm Muhammed b. Ahmed b. el-Hüseyn, Hilyetü'l'Ulemâ fi Ma'rifeti Mezâhibi'l-Fukehâ, tahk. Yasin ahmed İbrahim Dradeke, Müessesetü'r-Risâle/Darü'l-Erkâm, Beyrut/Amman 1980.

ŞEYHZADE, Abdurrahman b. Muhammed, Mecmeu'l-Enhur fî Serhi Mültekâ'lEbhur, İstanbul, 1311.

ŞİRÂZÎ, Ebû İshâk Cemâlüddîn İbrâhîm b. Alî b. Yûsuf, el-Mühezzeb fi Fıkhi'şŞâfi 'î, Dârü'l-Kütübi'l-İlmiyye, y.y. t.y.

ŞİRBİNî, Şemsüddîn Muhammed b. Ahmed el-Hatîb, Muğnî'l-Muhtâc, Dârü'lKütübi'l-İlmiyye, 1. Bask1, y.y 1994.

el-ìkna 'fi Halli Elfâzi Ebî Şüca', Dârü’l-Fikir, Beyrut, t.y. 